\title{
Large Scale Dew Collection as a Source of Fresh Water Supply
}

(For other water related R\&D done at NARI please visit this site)

\author{
Anil K. Rajvanshi ${ }^{1}$ \\ Director, Nimbkar Agricultural Research Institute (NARI) \\ Phaltan, Maharashtra, INDIA \\ Email: anilrajvanshi@gmail.com
}

\begin{abstract}
A scheme for large-scale dew collection as a source of fresh water supply is outlined in the present paper. The scheme envisages bringing cold seawater $\left(5^{0} \mathrm{C}\right)$ from about 500 meters depth and about $5 \mathrm{~km}$ from the shore, in four, $1.22 \mathrm{~m}$ diameter plastic pipes. It then passes through an onshore heat exchanger field with an area of $1.29 \times 10^{5} \mathrm{~m}^{2}\left(1.39 \times 10^{6} \mathrm{ft}^{2}\right)$ where it condenses $643 \mathrm{~m}^{3}$ of dew over the 24 hour period. The pumping of sea water from the sea and through the field is accomplished by three $200 \mathrm{~kW}$ wind machines. Technical and economical feasibility of the scheme is analyzed and the possibility of marine culture as a source of food is explored. The present scheme is economically not feasible as compared to a RO (reverse osmosis) facility of equivalent capacity.
\end{abstract}

\section{$\underline{\text { INTRODUCTION }}$}

With increasing industrialization and population, the world's water supplies are being taxed to their capacity. There is already an acute shortage of potable water in developing countries. This shortage has necessitated the use of desalination as a means of providing fresh water for drinking purposes. All of the existing desalination plants in the world use scarce and costly fossil to fire them. Consequently, the majority of these plants are located in Mid East countries [1]. However, the majority of the developing countries cannot get the costly fuel to run the desalination plants, thus pointing out the need of using alternative desalination technology.

One of the simplest desalination technologies that have received hardly any serious attention is the large-scale dew collection. Yet this is one of the major sources of water for plants and some animals in the coastal and inland deserts [2]. In the desert environment the dew collection takes place because of night sky radiation cooling. However, for production of large quantities of water the night sky radiation is not sufficient $[3,4]$. An alternative method, which is proposed in the present paper, is to pass the deep sea cold water through suitable heat exchangers for dew condensation. Obvious advantages of the scheme over the existing desalination processes are a) no energy is expended in evaporating the sea water - the air-sea

\footnotetext{
${ }^{1}$ This paper was written when the author was at Solar Energy and Energy Conversion Laboratory, Department of Mechanical Engineering, University of Florida, Gainesville, Florida 32611, U.S.A.
} 
interaction takes care of that, and b) because of assurance of constant temperature source of cold water, the dew collection can take place continuously day and night for the whole year.

This paper discusses the technical feasibility of such a scheme and the thrust is given to presenting an overall objective rather than detailed design calculations.

\section{SCHEME}

The scheme envisages bringing cold sea water at $4.5^{0} \mathrm{C}\left(40^{0} \mathrm{~F}\right)$ from about $500 \mathrm{~m}(1600 \mathrm{ft})$ depth in four, $1.22 \mathrm{~m}$ ( $4 \mathrm{ft}$ ) diameter plastic pipes to the shore. It then passes through a heat exchanger field (area of $1.29 \times 10^{5} \mathrm{~m}^{2}$ ), where it condenses about $643 \mathrm{~m}^{3}$ (170,000 gallons) of dew over the period of 24 hours. The pumping of sea water from the sea and through the heat exchanger is accomplished by three, $200 \mathrm{~kW}$ wind machines. After passing through the heat exchanger, the sea water goes through a series of ponds where algae and fish are grown. It then returns to the ocean.

Figure 1 shows the schematic of the scheme and Figure 2 is an artist sketch of the scheme. Below are detailed the different components of the system.

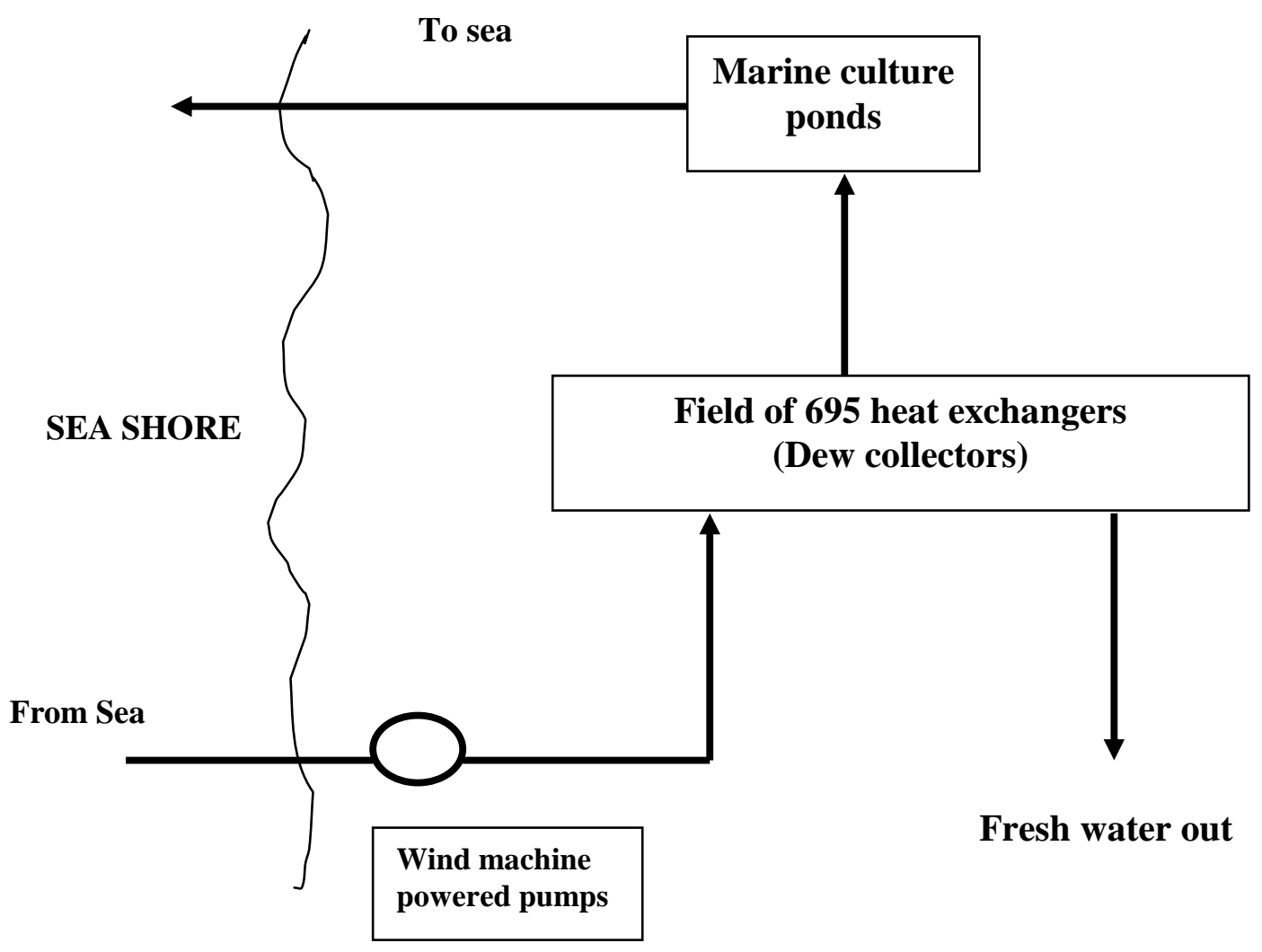

Fig. 1. Schematic of the scheme 


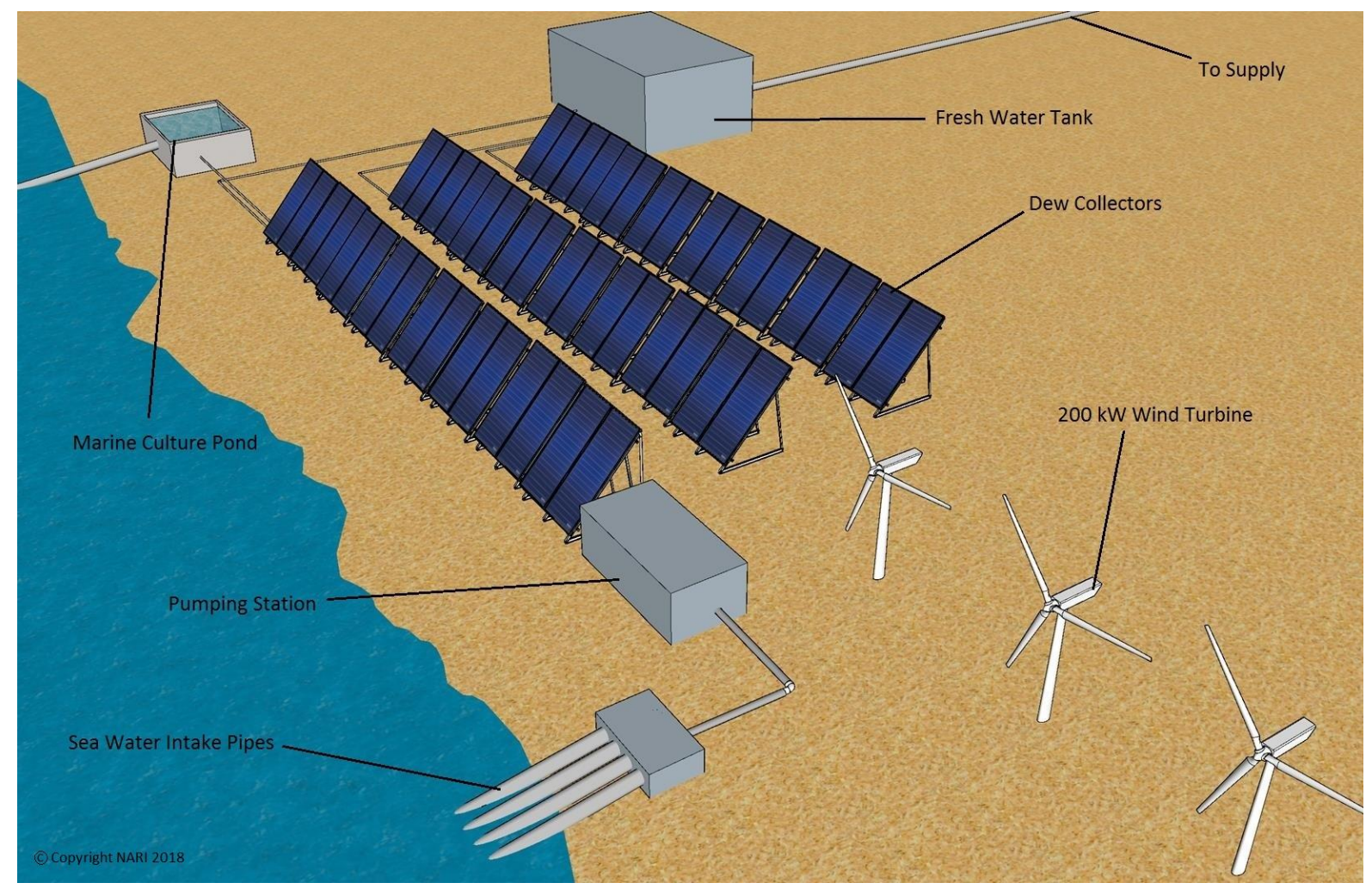

Fig. 2. Artist sketch of the scheme

\section{Heat Exchanger}

The condensation of dew takes place when the cold seawater passes through the heat exchanger. Thus the choice of heat exchanger is dictated by the following considerations; a) it should not be corroded by sea water, b) it should effectively exchange heat with environment and c) it should be inexpensive. Based on these points the heat exchanger chosen for the present scheme is an EPDM extruded collector [5]. These collector mats are used for medium temperature hot water heating. In this scheme the EPDM mat (without the glazing and the back insulation) sits on the shore inclined at an angle (about 60 to $70^{\circ}$ ) such that the dew condensation takes place on both sides of the mat.

The heat exchanger area for collecting the dew is calculated from the knowledge of condensation heat transfer coefficient. This coefficient has been obtained experimentally [4]. It should be noted that dew condensation will take place anytime when the heat exchanger plate temperature is less than the dew point of the ambient air. Thus even during daytime considerable condensation occurs. The heat exchanger area $A_{h}$ is therefore given as:

\section{During night :}

$$
\begin{aligned}
& 2 h_{c+r} A_{h}\left(T_{a}-T_{h}\right)+2 h_{\text {cond }} A_{h}\left(T_{a}-T_{h}\right)=m_{w} C_{p}\left(T_{\text {out }}-T_{\text {in }}\right) \\
& 2 h_{\text {cond }} A_{h}\left(T_{a}-T_{h}\right) t_{n}=m_{\text {dew }} h_{f g}
\end{aligned}
$$


During day:

$\alpha$ qs $A_{h}+2 h_{\text {cond }} A_{h}\left(T_{a}-T_{h}\right)+2 h_{c+r} A_{h}\left(T_{a}-T_{h}\right)=m_{w} C_{p}\left(T_{\text {out }}-T_{\text {in }}\right)$

$$
\mathrm{T}_{\mathrm{h}}=\frac{\mathrm{T}_{\text {out }}+\mathrm{T}_{\text {in }}}{2 \eta}
$$

and

$$
2 \mathrm{~h}_{\text {cond }} \mathrm{A}_{\mathrm{h}}\left(\mathrm{T}_{\mathrm{a}}-\mathrm{T}_{\mathrm{h}}\right) \mathrm{t}_{\mathrm{d}}=\mathrm{m}_{\text {dew }} \mathrm{h}_{\mathrm{fg}}
$$

The values of variables used in the above equations are shown in Table 1. For the night calculations it is assumed that the temperature of the sea water entering the heat exchanger module will be $10^{0} \mathrm{C}\left(50^{0} \mathrm{~F}\right)$ and that at the exit will be $15.5^{\circ} \mathrm{C}\left(60^{\circ} \mathrm{F}\right)$. Therefore the average temperature of the heat exchanger plate will be $12.7^{0} \mathrm{C}\left(55^{0} \mathrm{~F}\right)$. Since this plant will be on shore hence an average ambient temperature and relative humidity at night is assumed to be $23.8^{0} \mathrm{C}\left(75^{0} \mathrm{~F}\right)$ and $100 \%$ respectively. The duration of dew condensation at night is assumed to be 10 hours.

\section{Table 1}

Property values used in equations (1) to (5)

$\mathrm{h}_{\mathrm{c}+\mathrm{r}}=11.35 \mathrm{~W} / \mathrm{m}^{20} \mathrm{C}\left(2.0 \mathrm{BTU} / \mathrm{ft}^{2} \mathrm{hr}^{0} \mathrm{~F}\right)[13]$

$\mathrm{h}_{\text {cond }}=8.5 \mathrm{~W} / \mathrm{m}^{20} \mathrm{C}\left(1.5 \mathrm{BTU} / \mathrm{ft}^{2} \mathrm{hr}{ }^{0} \mathrm{~F}\right)[4]$

$t_{n}$; time for dew condensation at night $=10$ hours

Amount of dew condensed at night $=378 \mathrm{~m}^{3}(100,000$ gallons $)$

$\mathrm{t}_{\mathrm{d}} ;$ time for dew condensation during day $=14$ hours

Amount of dew condensed during day $=265 \mathrm{~m}^{3}$ (70,000 gallons)

Average ambient temperature at night $=23.9^{\circ} \mathrm{C}\left(75^{\circ} \mathrm{F}\right)$

Average ambient temperature during day $=26.6^{\circ} \mathrm{C}\left(80^{\circ} \mathrm{F}\right)$

Average solar radiation $=12.7 \mathrm{MJ} / \mathrm{m}^{2}\left(1120 \mathrm{BTU} / \mathrm{ft}^{2}-\right.$ day $)$

Relative humidity 100\%

$\eta$, heat exchanger efficiency $=0.9$

All the above property values are taken as average conditions for locations between $30^{\circ} \mathrm{N}$ and $30^{\circ} \mathrm{S}$ latitudes.

For the daytime calculations average solar radiation and ambient temperature have been assumed. Thus over a period of 14 hours the solar radiation is assumed to have a value of about $252 \mathrm{~W} / \mathrm{m}^{2}$ (80 $\left.\mathrm{BTU} / \mathrm{ft}^{2} \mathrm{hr}\right)$ and ambient temperature of $26.6^{\circ} \mathrm{C}\left(80^{\circ} \mathrm{F}\right)$. These are reasonable assumptions for sea shore 
conditions [6]. From equation (1) the mass flow rate of sea water flowing through the heat exchangers is calculated and is $8.31 \times 10^{6} \mathrm{~kg} / \mathrm{hr}\left(18.3 \times 10^{6} \mathrm{lbs} / \mathrm{hr}\right)$. This value is held constant during the daytime also.

Each collector module is assumed to be $18.6 \mathrm{~m}^{2}(50 \mathrm{ft} \mathrm{X} 4 \mathrm{ft})$ in area. This choice of area has been dictated by the ease of maintenance and installation. Thus the total number of collectors is 6950 . It should be pointed out that the value of $h_{c+r}$ in equations (1) and (3) is that for still air. Near the sea shore the conditions are far different from still air. However, the collectors are arranged such that they are normal to the direction of the wind (coming from the sea) and thus act as wind breakers, thereby justifying the assumption of $\mathrm{h}_{\mathrm{c}+\mathrm{r}}$.

\section{$\underline{\text { Sea Water Intake Pipes }}$}

The choice of sea water intake pipe is governed by the following considerations; a) it should be noncorrosive with sea water b) it should withstand the tides and the wave motions, c) it should provide excellent insulation for the cold water during its passage to the shore and d) it should be easily assembled. Based on these criteria the pipe chosen for the present scheme is a $1.22 \mathrm{~m}(4 \mathrm{ft})$ diameter plastic pipe with wall thickness of $3.7 \mathrm{~cm}$ (1.45 inches) [7]. Four such pipes will bring the required water to the shore.

The cold sea water of $4.5^{\circ} \mathrm{C}\left(40^{\circ} \mathrm{F}\right)$ is mostly located at a depth of about $500 \mathrm{~m}(1600 \mathrm{ft})$ [8]. Moreover, the present scheme has been designed for locations where about $500 \mathrm{~m}$ deep waters are available at about $5 \mathrm{~km}$ or less distance from shores [9]. Heat transfer calculations for a $5 \mathrm{~km}$ plastic pipe show that the temperature rise of cold water of $4.5^{0} \mathrm{C}\left(40^{0} \mathrm{~F}\right)$ will be less than $0.27^{0} \mathrm{C}\left(0.5^{0} \mathrm{~F}\right)$ in reaching the shore. Thus the plastic pipe provides adequate insulation. These calculations have been performed assuming a sea water temperature profile [8] and the flow rate of water of $2.1 \times 10^{6} \mathrm{~kg} / \mathrm{hr}\left(4.6 \times 10^{6}\right.$ $\mathrm{lbs} / \mathrm{hr})$.

\section{Pumping Requirements}

Table 2 shows the pressure drop in various sections of the scheme and the pumping requirements. The total pressure drop is about $176 \mathrm{kPa}$ ( $60 \mathrm{ft}$ of water). Near the sea shore there is a constant wind and thus it is appropriate that the wind machines be used to operate the pumps. Three $200 \mathrm{~kW}$ wind machines will adequately perform the pumping of sea water through collectors. Since the wind is constant near the shore no attempt has been made to store the water in the overhead tanks. This storage would have been necessary to overcome the pumping loss during wind-lean periods. It is also interesting to note that any energy input in the present scheme is that from the wind machines which make this scheme consume $\cong 57$ $\mathrm{kW}$ hr/1000 gallons. This energy requirement compares very favorably with that used in RO units ( $65 \mathrm{~kW}$ $\mathrm{hr} / 1000$ gallons), and MSF (315 kW hr/1000 gallons) [10]. This is to be expected since no energy is expended in evaporating the water. 


\begin{tabular}{|c|c|c|}
\hline \multicolumn{3}{|c|}{ Table 2} \\
\hline & $\begin{array}{l}\text { Pressure drop } \\
\mathrm{kPa}(\mathrm{ft} \text { of } \\
\text { water) }\end{array}$ & $\begin{array}{l}\text { Flow rate } \\
\mathrm{kg} / \mathrm{hr}(\mathrm{lbs} / \mathrm{hr})\end{array}$ \\
\hline Sea water intake pipe (4, plastic) & $19.4(6.5)$ & $2.1 \times 10^{6}\left(4.6 \times 10^{6}\right)$ \\
\hline Header to modules ( 3 , plastic) & $113(38)$ & $4.2 \times 10^{6}\left(9.2 \times 10^{6}\right)$ \\
\hline Header of modules (20, plastic) & $23.9(8)$ & $0.82 \times 10^{6}\left(1.8 \times 10^{6}\right)$ \\
\hline Collectors (6950, EPDM) & $11.9(4)$ & $1.2 \times 10^{3}\left(2.6 \times 10^{3}\right)$ \\
\hline Return pipe to sea ( 1 , concrete $)$ & $5.97(2)$ & $8.32 \times 10^{6}\left(18.3 \times 10^{6}\right)$ \\
\hline Total pressure drop & $176(59)$ & $8.32 \times 10^{6}\left(18.3 \times 10^{6}\right)$ \\
\hline \multicolumn{3}{|c|}{ Power requirements of about $450 \mathrm{~kW}$} \\
\hline Number of wind machines @ 200 & & \\
\hline
\end{tabular}

Mariculture ponds

The deep sea water is an excellent feed producer for mariculture crops [9]. After passing through the heat exchanger it can easily be run into deep ponds ( $\cong 6 \mathrm{~m}$ deep) to produce algae, which is a rich protein source. These algae then can be a source of food for growing fish and clams [9]. Thus besides providing the much needed water for the locality this scheme will also provide a source of protein and food. Based on the results of the pioneering work done in the St. Croix island by Roels and his group [9], the present scheme will produce about 870 tons/year (wet weight) of shellfish. It should be noted that in the existing desalination plants such a scheme (of mariculture) cannot be implemented because of lack of deep sea water.

Finally for the sake of completeness of the study a preliminary economic analysis of the scheme has been done. Assuming the cost of wind machines at $\$ 600 / \mathrm{kw} \mathrm{[11],} \mathrm{the} \mathrm{cost} \mathrm{of} \mathrm{heat} \mathrm{exchangers} \mathrm{at} \$$ $30 / \mathrm{m}^{2}\left(\cong \$ 3 / \mathrm{ft}^{2}\right)[5]$ and the cost of $1.22 \mathrm{~m}(4 \mathrm{ft})$ diameter plastic pipe at $\$ 262 / \mathrm{m}(\$ 80 / \mathrm{ft})$, the capital cost of the scheme comes out to be $\$ 11$ million. The price of this scheme should be compared with the existing desalination plant of an equivalent capacity. For comparison we have assumed a reverse osmosis (RO) scheme [12]. Even taking the escalating fuel prices (at 15\% annual increase) into account it has been found that RO plant will be cheaper than the existing scheme by a factor of 2.5. However, if the fuel prices suddenly double or triple then the present scheme (dew collection) will become economically viable. It should be pointed out that the whole purpose behind presenting the idea of dew collection is to create awareness of the technical merits of this scheme. Nevertheless, it is felt that with better technology and 
materials of various components the scheme has capability of becoming economically viable. For example the two main components with the highest price tags are the heat exchanger field (\$4.2 million) and sea water intake pipes ( $\$ 5.3$ million) respectively. If the field can be made of tubular heat exchangers rather than the flat plate (as the present scheme) considerable savings in the cost can be achieved. In the absence of any experimental data on dew collection on tubular heat exchangers we have chosen the flat plate (for which the data exists [4]). Similarly cheaper pipes for sea water intake will reduce the cost of the scheme.

It can also be conjectured that in the future the OTEC (Ocean Thermal Energy Conversion) schemes may very well become floating desalination plants with the cold water from the bottom used for dew condensation. The production of fresh water may make OTEC economically viable since the generated commodity (in this case fresh water) can be easily transported to shore in huge plastic tankers. Right now no viable scheme of getting the generated power from OTEC plants to the shore exists [9].

\section{CONCLUSIONS}

The following conclusions can be drawn based on the present study.

1. Large scale dew collection near the seashore for production of fresh water is technically feasible.

2. A heat exchanger field of area $1.29 \times 10^{5} \mathrm{~m}^{2}\left(1.39 \times 10^{6} \mathrm{ft}^{2}\right)$ can condense $643 \mathrm{~m}^{3}$ (170,000 gallons) of dew over a period of 24 hours.

3. The cold water for dew condensation is obtained from a depth of about $600 \mathrm{~m}$. The pumping of 8.32 $\mathrm{X} 10^{6} \mathrm{~kg} / \mathrm{hr}\left(18.3 \times 10^{6} \mathrm{lbs} / \mathrm{hr}\right)$ of this cold water is achieved by $3,200 \mathrm{~kW}$ wind machines.

4. This present scheme is economically not feasible as compared to a RO facility of equivalent capacity.

Acknowledgements : The author wishes to thank Richard Dixon, Kris Kirtikara and Rolando S. Guerra at UF in helping in the dew condensation experimental set up and data collection. And to Rahul Pisharody of NARI for making the artist sketch of the scheme.

\section{REFERENCES}

1. P. M. Morris, "Desalination of Sea Water", Chemistry \& Industry, August 6 (1977).

2. Uwe George, In the Deserts of this Earth, Harcourt Brace Jovanovich Inc., New York (1979).

3. J. L. Monteith, "Dew", Quarterly Journal, Royal Meteorological Society, Vol. 83, pp. 322-341 (1957). 
4. A. K. Rajvanshi, "Heat and Mass Transfer in Dew Collection", in preparation.

5. Bio Energy Systems, Inc., Personal Communication.

6. B. Y. Liu and R. C. Jordan, "Availability of Solar Energy for Flat - Plate Solar Heat Collectors", in Applications of Solar Energy for Heating and Cooling of Buildings (Eds. B. Y. Liu and R. C. Jordan), ASHRAE GRP 170 (1977).

7. Steve Campbell, Personal Communication.

8. F. Kreith and J. F. Kreider, Principles of Solar Engineering, McGraw Hill Book Company, New York (1978).

9. O. A. Roels, "Food, Energy and Fresh Water", Mechanical Engineering, June (1980).

10. R. S. Silver and W. S. McCartney, Desalination, in The Marine Environment (Eds., Lenihan and Fletcher), Vol. 5, Academic Press, New York (1977).

11. Anonymous, Wind Product Supplement, Solar Age, February (1980).

12. CH2M Hill, The U.S.A.I.D. Desalination Manual, Office of Engineering, U.S.A.I.D. Washington, D.C., Contract AID/OTR-C-1618 (1980).

13. B. Gebhart, Heat Transfer, McGraw Hill Book Company, New York (1961).

\section{NOMENCLATURE}

$\mathrm{A}_{\mathrm{h}} \quad$ heat exchanger area, $\mathrm{m}^{2}$

$\mathrm{C}_{\mathrm{p}} \quad$ specific heat, $\mathrm{kJ} / \mathrm{kg}{ }^{0} \mathrm{C}$

$\mathrm{h}_{\mathrm{fg}} \quad$ enthalpy of vaporization, $\mathrm{kJ} / \mathrm{kg}$

$\mathrm{h}_{\mathrm{c}+\mathrm{r}} \quad$ combined convection and radiation heat transfer coefficient, $\mathrm{W} / \mathrm{m}^{20} \mathrm{C}$

$\mathrm{h}_{\text {cond }} \quad$ condensation heat transfer coefficient, $\mathrm{W} / \mathrm{m}^{20} \mathrm{C}$

$\mathrm{m}_{\text {dew }} \quad$ amount of dew condensed, $\mathrm{kg}$

$\mathrm{m}_{\mathrm{w}} \quad$ rate of sea water flow, $\mathrm{kg} / \mathrm{hr}$

$\mathrm{q}_{\mathrm{s}} \quad$ incident solar radiation, $\mathrm{W} / \mathrm{m}^{2}$

$t_{d} \quad$ duration of dew condensation during day, hrs.

$t_{n} \quad$ duration of dew condensation during night, hrs.

$\mathrm{T}_{\mathrm{a}} \quad$ ambient temperature, ${ }^{0} \mathrm{C}$

$\mathrm{T}_{\mathrm{h}} \quad$ temperature of heat exchanger place, ${ }^{0} \mathrm{C}$

$\mathrm{T}_{\text {in }}, \mathrm{T}_{\text {out }} \quad$ temperature of sea water entering and leaving the heat exchanger respectively, ${ }^{0} \mathrm{C}$

\section{Greek letters}

$\alpha \quad$ solar absorptivity of the EPDM mat

$\eta \quad$ heat exchanger efficiency

A short history of water related R\&D at NARI is here.

CNARI. 2018 